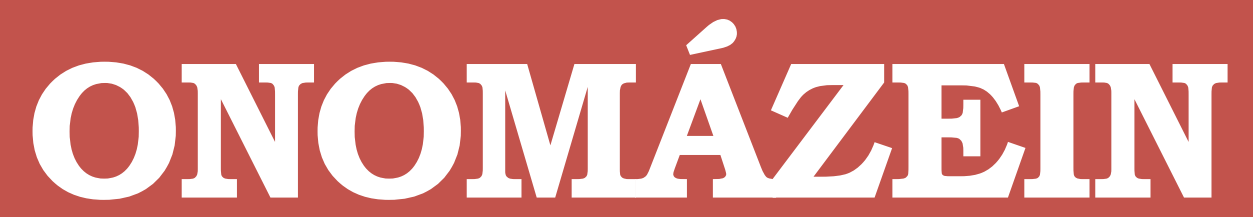

Journal of linguistics, philology and translation

\title{
Training in gender and sexual identities in EFL teaching. Participants' contributions
}

\section{Stefano Barozzi}

Universidad de Granada

\section{Raúl Ruiz Cecilia}

Universidad de Granada

Special

Issue

- VI -

Language

Teaching

Research from a Global

Perspective

2020
ONOMÁZEIN | Special Issue VI - Language Teaching Research from a Global Perspective: 84-103 DOI: 10.7764/onomazein.ne6.05

ISSN: 0718-5758

\section{(c) $($ i $)$}

Stefano Barozzi: Facultad de Ciencias de la Educación, Universidad de Granada | E-mail: stef@ugr.es Raúl Ruiz Cecilia: Facultad de Ciencias de la Educación, Universidad de Granada | E-mail: raulruiz@ugr.es 


\section{Abstract}

This paper is based on a training course which took place at the University of Granada (Spain) with the general purpose of introducing and discussing queer issues in EFL (English as a Foreign Language) teaching. The specific aim was to empower primary and secondary school pre-service EFL teachers in order to take pedagogical action in favour of LGBTIQ+ persons' equity. In this action research study, emphasis was put on practical activities, including the production of original queer teaching materials, and class interactions based on queer theory and transformative pedagogy. Qualitative data, emerged from the participants' written and oral course evaluations as well as class observations, were examined through thematic analysis, which served to improve further editions of the course. The main results of this study suggest that this type of training should begin in early childhood education, that it is necessary to train EFL (as well as any other discipline) pre-service teachers in these issues and that progressive Spanish legislation for LGBTIQ+ people might not be sufficient in itself unless it is adequately implemented in education.

Keywords: EFL; heteronormativity; LGBTIQ+phobia; queer theory; teacher training. 


\section{Introduction}

As part of a PhD study (Barozzi, 2016) at the Faculty of Education of the University of Granada (Spain), we offered a training course for pre-service primary and secondary school EFL teachers in gender and sexual identities in which we turned to our own teaching and learning experience, as we had been learners of English ourselves. We both experienced that during our learning process and our teacher training experience, gender and sexual identities, apart from ubiquitous heterosexuality, were never shown in textbooks and never mentioned in class. However, these sociocultural identities are part of our reality and, therefore, should be included and discussed in EFL teaching, especially because there are EFL students and teachers who might not identify themselves as 'cis' heterosexual (please read below for the explanation of 'cis') or gender non binary, and should be therefore taken into account (Nelson, 2009).

As EFL teachers, we have experienced many occasions in which queer issues came up spontaneously during the lessons and often we had to deal with them without knowing exactly what to do. It is our belief that training in gender and sexual identity issues in education, including EFL teaching, is necessary if we want to counteract the gender binary system, Igbtiq+phobia ${ }^{1}$, heterosexism and cissexism (please read below for the explanation of these terms) as forms of social discrimination and injustice by generating knowledge and better understanding.

At the beginning of our study we were confronted by indifference and denial of the problem (Igbtiq+phobia, heterosexism) expressed by some EFL colleagues (in ESL_English as a Second Language-see Nelson, 1993) and primary and secondary school teachers in Granada that we interviewed, who, after observing cases of Igbtiq+phobia, like direct insults and reported threats, and after talking to their students, admitted that it was very important to address these issues in their classes.

This work is inspired by queer theory (mainly based on Nelson's studies, 1993, 1999 and 2002), although critical and transformative pedagogies (drawn on Bedford, 2009) have been taken into account, which served as a vehicle to organise the course and were discussed in class, although more relevance was given to practical activities. It is based on qualitative data analysis through action research in the classroom. We acted as teachers/facilitators and researchers at the same time. Thus, the participants' accounts are fundamental contributions to this study.

1 We prefer to write Igbtiq+ in small letters, although it is an acronym, because the capital letters stand out in a text and these words are mainly used as adjectives. 
Queer language was of paramount importance in our course as well as in this paper. The terms discussed in the course are not universal and each person might interpret them in a slightly different and personal way, just like the words in the acronym Igbtiq+. Heterosexism is the belief that heterosexuality is the only possible natural sexual identity whilst all others are considered to be inferior and deviant. Heteronormativity, with its social norms and rules, perpetuates heterosexism; however, unlike Igbtiq+phobia, which is intentional in nature, heteronormativity is often (sub)consciously reproduced in everyday interactions, texts, images and discourses, and therefore it could be more difficult to counteract.

The use we make in this text of the word queer, which is a problematic term per se, is polyvalent as it is used both as an umbrella term for Igbti and also as a fluid term which rejects fixed gender categorisations (drawn on Jagose, 1996), such as genderqueer individuals, who do not accept the dichotomy woman (she) and man (he), and fluid ones, who sometimes feel more female and others more male, and may adopt the non-binary singular pronouns ze or they for themselves; and those who might consider themselves 'more or less men' or 'more or less women', as nobody could be totally 'male' or totally 'female' (Pérez, 2012). Pansexual, asexual and even heterodissident² people could also join the queer rubric. 'Gender and sexual identities', unlike 'queer identities', also include (cis) heterosexuality, which, according to queer theory, should be problematised by discussing its hegemonic role in our society (Foucault, 1976; in ESL see Nelson, 2002, 2009). If the term heterosexual is not accompanied by the affix cis, which is the opposite of trans, it might be problematic, as some trans people might define their sexual orientation as heterosexual. Cis (cisgender/cissexual) people, unlike trans people, feel comfortable with their sex assigned at birth as well as their assigned sociocultural gender (drawn on Serano, 2007). Cissexism is the belief that cis people are superior to trans people. This can be manifested in different ways, like, for example, not allowing a trans woman to enter and use a lavatory for women based on the assumption that she was born male, or an intended misuse of gender pronouns.

As for EFL education, although English has become one of the most important school subjects throughout the world, queer identities are consistently omitted in EFL and ESL pedagogical practices (Thornbury, 1999; Nelson, 2009; Gray, 2015). However, since the early 1990s, there has been growing interest in discussing gender and sexual identities in foreign and second language education (drawn on Nelson, 2009). Yet, at the beginning of our research we could not find sufficient material to support our study in relation to EFL and queer issues, as confirmed by Nelson (2009: xiv): "for there were few, if any, resources offering guidance in dealing with the intriguing teaching dilemmas that arose with regard to sexual identities".

2 We describe hetorodissident anybody who considers themselves as cisgender and straight but do not accept as 'natural' their hegemonic and superior role in our society. They act as allies for all Igbtiq+people's rights. 


\subsection{Justification and Spanish legislation}

In the education industry, Igbtiq + and gender nonconforming adolescents are at much higher risk of attempting or committing suicide than their cis-heterosexual counterparts, as reported in a Spanish study undertaken by FELGTB (2013)3, which underlines the failure of the Spanish educational system in its attempt to stop Igbtiq+phobic bullying in education. As suggested by Robinson \& Jones Díaz (2006), gender nonconforming children start to struggle at an early age when Igbtiq+phobia is perceived, hence the need to take action in education as early as possible.

To justify this work even further, we have analysed some EFL textbooks adopted in state-run primary schools in Granada and noticed how heteronormativity was present in nearly every unit and how Igbtiq + persons and any reference to gender and sexual identities (apart from cis-heterosexuality) were totally absent (e.g. Blair \& Cadwallader, 2009; Papiol \& Toth, 2009). The main idea of offering a training course in gender and sexual identities in EFL education was born from the results of a pilot study (Barozzi \& Guijarro-Ojeda, 2014, 2016) in which the participants, pre-service and in-service primary school EFL teachers, requested to be trained in gender and sexual identity issues.

With regard to the legal situation in Spain, sexual orientation, personal identity and individual differences in education are protected by the Spanish Constitution (1978) and education legislation (LOMCE, 2013)4. In both state-run and to a lesser extent private and religious (mostly Catholic) Spanish primary and secondary schools, sexual identity issues could be addressed through cross-curricular themes in almost any school subject, but they are never part of the explicit curriculum and therefore are not usually mentioned.

An innovative educational law was passed in Andalusia in 2016 (II Plan for Gender Equality in Education)5, which demands more recognition and protection for lgbt persons and gender diversity in education. Since 2005 homosexual couples in Spain can get married and adopt children, and since 2007 all over Spain trans people can change their gender and name following a two-year period of psychological and medical attention and without having to go through gender confirmation surgery. Moreover and more significantly, a ground-breaking law was passed in Andalusia in $2014^{6}$ (modified in 2016) and two similar ones in the community of Madrid and the Balearic Islands in 2016 (these last two also include the prohibition of genital mutilation on intersex babies), which allow trans people to change their name and

3 FELGTB (Federación Estatal de Lesbianas, Gays, Transexuales y Bisexuales): http://www.felgtb.org/ rs/2157/d112d6ad-54ec-438b-9358-4483fgeg8868/671/filename/informedefensor 17m13.pdf.

4 https://www.boe.es/diario_boe/txt.php?id=BOE-A-2013-12886.

5 http://www.juntadeandalucia.es/boja/2016/41/BOJA16-041-00023-3564-01_00086188.pdf.

6 https://www.boe.es/buscar/doc.php?id=BOE-A-2014-8608. 
gender without going through medical, psychological and legal attention, including the possibility of administering hormone replacement therapy to trans minors during puberty, thus depatholigising transsexuality. Despite progressive Spanish legislation, there are not specific school subjects that address queer identities or Ibgitq+phobia in Spanish education and often teachers do not feel confident to discuss the issue.

\section{Previous research studies}

Research studies based on practical training courses on gender and sexual diversity for primary and secondary school EFL student teachers do not seem to exist in Spain. There are Spanish, European and wider international studies on teachers' and students' understandings of queer issues in general education (e.g. Bickmore, 1999; Kissen, 2002; Berg, 2012; Brant, 2017; and in Spain another research coordinated by FELGBT in 20077). The main results of these studies convey that homophobia is still a serious problem at all educational levels.

Spanish research (Penna Tosso, 2012) shows that secondary school teachers in Madrid have never received specific training in how to deal with sexual diversity issues despite requesting it. Similar results were obtained in a study at the Faculty of Education in Malaga (Gallardo \& Escolano, 2009), where university students and professors also requested training in sexual identity issues, just like the main result from the pilot study that preceded this training course (Barozzi \& Guijarro-Ojeda, 2014, 2016). All these studies demonstrate that one of the best ways to counter Igbtiq+phobia and heterosexism in education is to develop pre-service and in-service teacher training programmes.

As for English language education, the most relevant studies for our research are those undertaken by Nelson (1993, 1999, 2003, 2009), which are in connection with ESL, queer theory and adult education. Whilst the ubiquitous presence of heteronormativity in teaching materials, which was addressed in the course, is discussed and problematised by Sunderland \& McGlashan (2015) in EFL textbooks, Paiz (2015) in ESL reading texts and textbooks, and Way (2016) in ELT materials. Some other international studies that address gender and sexual diversity within foreign language teaching are those carried out by De Vincenti et al. (2007), Hanauer (2007), Gray (2015) and, in Spain, Guijarro Ojeda (2006, 2004) and Guijarro Ojeda \& Ruiz Cecilia (2011, 2013).

There are fewer research studies on gender and sexual identities based on teacher training courses and programmes. The most inspiring training course for this study is the GLEE (Gay and Lesbian Educational Equity) Project (Bedford, 2009), which provided training courses throughout Europe that empowered in-service secondary as well as primary school teachers

7 http://www.felgtb.org/rs/467/dı12d6ad-54ec-438b-9358-4483fgeg8868/c11/filename/adolescentes-ante-la-diversidad-sexual2.pdf. 
to help create safe and affirmative schools for Igbt students and staff. It did not deal with $E F L$, but with a range of different subject areas. There are various educational projects and Igbtiq+ organisations all over the world that offer training courses on how to address sexual identity issues and Igbtiq+phobia in education; however, we could not find published works on practical training courses specifically aimed at EFL student teachers in Spain.

\section{Theoretical framework: Queer theory and transformative pedagogy}

Queer theory started with, or was caused by, the Aids crises of the mid 1980s in the United States and stems from French poststructuralism. Poststructuralists consider identities as social and cultural constructs, with people acting out their own social identity on a daily basis in specific ways according to a particular culture and period of time (Butler, 1990; in ESL see Nelson 2002, 2009). Moreover, queer theory problematises (cis) heterosexuality because of its hegemonic role in society. This pedagogical approach has been proved to be very useful in education (e.g. Hermann-Wilmarth \& Bills, 2010; Bower \& Sature, 2012; Kuzmic, 2014; Taylor \& Coia, 2014; Murray, 2015; McEntarfer, 2016; Staley \& Leonardi, 2016) since it enables students to conduct more inclusive discussions and to question the hegemony of heterosexuality rather than only discussing subordinate gender and sexual identities in an uncritical way without challenging power relationships in society (Foucault, 1976; in ESL see Nelson, 2002). In fact, a universalising approach may actually be more 'inclusive' than simply validating subordinate sexual identities, because it allows for a wider range of experiences and perspectives to be considered. It may also be more practicable, since teachers or trainers are not expected to transmit knowledge, which they may or may not have, but to frame tasks that encourage investigation and inquiry (drawn on Nelson, 2002: 48).

According to Nelson (2002: 47), from a teaching and learning perspective, there are many advantages to considering gender and sexual identities as culturally readable acts rather than universal essences.

Furthermore, primary school pupils already possess much (mis)information about gender and sexual diversity which needs to be readdressed and reoriented (Bickmore, 1999; Robinson \& Jones Díaz, 2006). Jennings (1999) reports that antigay prejudice starts as early as kindergarten and becomes more manifest among pupils and often teachers in primary education. In line with the pedagogy used in the course, Sears (1999: 5) describes queer pedagogy as "creating elementary classrooms that challenge categorical thinking, promote interpersonal intelligence, and foster critical consciousness". The documentary It's elementary. Talking about gay issues in schools (Chasnoff \& Cohen, 1996), which was shown and discussed in the course, was filmed in six US elementary and middle schools and deals with children's evolutionary age; it is a milestone in the development of pedagogic discourse in primary and secondary teacher training programmes on gender and sexual identities. The film shows that it is possible to establish constructive discussions with primary school pupils on gay and lesbian issues in a natural and critical way. 
Transformative pedagogy (Bedford, 2002, 2009; originated by Freire, 1975, and Giroux, 1997) stems from critical theory (first introduced by Horkheimer in 1976) and "aims to create critical consciousness and to promote an analysis of the processes of mindset construction. Its methodology addresses inequity and discrimination by deconstructing stereotypes and prejudices" (Bedford, 2002: 138).

Transformative pedagogy shares similarities with queer pedagogy because both consider gender and sexual identities to be socially and historically constructed; therefore, for both pedagogies it is fundamental to deconstruct Igbtiq+phobia and heterosexism in education through desocialisation (Bedford, 2009). The methodology of the training course discussed in this paper privileged emic (insider) over etic (outsider) knowledge, and reinforced the concept that subjective knowledge and truth can only be recognised in a specific and locally constructed social reality (Bedford, 2009: 50); in the case of this course, the locally constructed social reality was represented by Granada and Andalusia.

\section{Course organisation and structure}

Partly based on the structure of the GLEE Project (Bedford, 2009), the course was an interactive programme of student teacher training and pedagogical strategies to counter Igbtiq+phobia and heterosexism in primary and secondary school English-language education in Spain. Through critical thinking and participatory inquiry, the trainees had to propose queer pedagogical initiatives and activities in the area of EFL. They received a latent empowerment (Bedford, 2009) in order to take action against discrimination based on gender identity and sexual orientation in both primary and secondary education once they become in-service teachers. The course did not take place in a formal teacher training programme, but was provided by the University of Granada as part of other courses for undergraduate and postgraduate students. Participation was voluntary and the course was mainly aimed at primary school EFL student teachers; a lower intermediate level in English (B1) was required. Participants had to pay a fee and, upon completion of the course, they received four university credits. The course lasted forty hours, it was divided into ten sessions of four hours each, was offered twice weekly and given entirely in English. It was based on a communicative and interactive method, through workshops, class interactions and theoretical discussions.

Almost each session was accompanied by practical workshops, usually group works; some were adapted from The Leadership Training Course of the GLEE Project (GLEE, 2002), whilst others were based on our own teaching experience in the field. At the end of the course the participants presented six queer teaching projects in small groups. Four were aimed at primary school pupils and two at secondary school students. To develop their projects, based on teaching units, the participants used authentic materials in English, such as queer children's books for primary school level (e.g. Fierstein, 2002; Valentine, 2004; Ewert, 2008) to present a variety of family units, and to discuss difference and gender nonconformity as positive 
human values. For secondary school level, two films were chosen (Boys don't cry, Kimberly Peirce, 1999, and Brokeback Mountain, Ang Lee, 2005) to critically uncover and discuss heterosexism, Igbtiq+phobia and cissexism with the students.

\subsection{Results from the pre-course questionnaire: The participants}

\section{TABLE 1}

Participants' main variables

\begin{tabular}{|c|c|c|c|c|c|}
\hline GENDER & AGE & SEXUAL IDENTITY & EDUCATION & $\begin{array}{c}\text { ENGLISH } \\
\text { PROFICIENCY }\end{array}$ & $\begin{array}{l}\text { TEACHING } \\
\text { PRACTICE }\end{array}$ \\
\hline P1. W & 21 & Heterosexual & EFL for primary education & Intermediate & $\begin{array}{l}\text { Yes, three } \\
\text { months }\end{array}$ \\
\hline P2. W & 21 & Heterosexual & EFL for primary education & Elementary & Yes, five months \\
\hline P3. W & 21 & Heterosexual & $\begin{array}{l}\text { EFL for secondary } \\
\text { education }\end{array}$ & Advanced & No \\
\hline P4. W & 21 & Heterosexual & $\begin{array}{l}\text { EFL for secondary } \\
\text { education }\end{array}$ & Advanced & $\begin{array}{l}\text { Yes, two } \\
\text { summers }\end{array}$ \\
\hline P5. W & 22 & Heterosexual & EFL for primary education & Intermediate & $\begin{array}{l}\text { Yes, four } \\
\text { months }\end{array}$ \\
\hline P6. W & 22 & Heterosexual & EFL for primary education & Intermediate & Yes, five months \\
\hline P7. W & 23 & Heterosexual & EFL for primary education & $\begin{array}{l}\text { Lower } \\
\text { intermediate }\end{array}$ & No \\
\hline P8. W & 23 & Heterosexual & EFL for primary education & Intermediate & $\begin{array}{l}\text { Yes, four } \\
\text { months }\end{array}$ \\
\hline P9. W & 25 & $\begin{array}{l}\text { Mainly heterosexual, } \\
\text { but flexible }\end{array}$ & PhD in Gender Studies & Advanced & No \\
\hline P10.W & 26 & $\begin{array}{l}\text { Heterosexual, but } \\
\text { does not follow } \\
\text { stereotypes }\end{array}$ & Degree in History & Advanced & No \\
\hline P11. W & 27 & $\begin{array}{l}\text { Heterosexual, but } \\
\text { who knows? }\end{array}$ & EFL for primary education & Advanced & $\begin{array}{l}\text { Yes, four } \\
\text { months }\end{array}$ \\
\hline P12. W & 32 & Heterosexual & EFL for primary education & Intermediate & Yes, five months \\
\hline P13. M & 20 & $\begin{array}{l}\text { Heterosexual, } \\
\text { but not sure }\end{array}$ & EFL for primary education & Elementary & Yes, five months \\
\hline P14. M & 22 & Heterosexual & EFL for primary education & Intermediate & Yes, six months \\
\hline P15. M & 23 & Heterosexual & $\begin{array}{l}\text { EFL for secondary } \\
\text { education }\end{array}$ & Advanced & No \\
\hline P16. M & 30 & Homosexual & $\begin{array}{l}\text { PhD in Gender and } \\
\text { Equality Politics }\end{array}$ & $\begin{array}{l}\text { High } \\
\text { intermediate }\end{array}$ & No \\
\hline
\end{tabular}


General information and basic queer knowledge of the participants were gathered using an anonymous questionnaire which was completed on the first day of class. As shown in table 1 (Participants' main variables), sixteen trainees participated, aged between 21 and 32. 'Women - W' (12) outnumbered 'men - M' (4) by far, which, in our own experience, is rather common in foreign language education, at primary school level and when dealing with gender and sexual diversity. Therefore, although there was a disproportion between 'women' and 'men', this reflected reality. However, not everybody considers themselves to be a woman or a man, or to be female or male; we believe that the term 'gender' is polyvalent and open to various possibilities and not only restricted to the gender binary system (female or male, man or woman). Nonetheless, in the initial questionnaire, the participants described their gender to be either female/woman ( $F$ - W) or male/man (M); so, we have respected their choice and used $W$ for women and $M$ for men in table 1.

The vast majority considered themselves to be (cis) heterosexual and did not possess a sufficient knowledge of gender and sexual diversity prior to the course; the majority (see table 1 ) possessed an intermediate or higher intermediate level of English. Nobody in the course had ever received training in gender and sexual diversity, although they all expressed its importance for their professional career.

Everybody knew the meaning of Igbt, but ' $i$ ' for intersexual was unknown by thirteen of them. Only P16 and P9 gave a definition of 'queer' close to its meaning as in queer theory, due to their gender studies experience. Likewise, only P9, P10 and P16 knew what heterosexism and heteronormativity meant. Homophobia ${ }^{8}$ was understood by all as a form of social discrimination. In one question they were asked what caused their 'heterosexuality' (from Martin Rochlin's 1972 Heterosexual questionnaire9) and eight participants replied 'queerly' by stating that their 'heterosexuality' was felt as a social imposition. They understood the importance of addressing gender and sexual diversity in English language education as well as in any other school subject. Ten out of sixteen participants thought that primary school children were not capable of discussing gender and sexuality issues through critical thinking. Moreover, eleven admitted that teaching gender and sexual diversity to secondary school students was easier than teaching it to primary school pupils. Parental reaction to addressing non-normative gender and sexual identities in schools was feared by half of the participants as they found the issue too delicate to be understood by parents/guardians especially at primary school level. Inclusion of a family with homosexual parents/guardians in an English language textbook was considered feasible by thirteen participants; although $\mathrm{P} 1, \mathrm{P} 8$ and $\mathrm{P} 13$ believed that this kind of inclusion could be problematic as it might be too early for Spanish society.

8 Homophobia was the term used in the questionnaire as it is the most commonly known.

9 https://www.uwgb.edu/pride-center/files/pdfs/Heterosexual_Questionnaire.pdf. 


\section{Participants' contributions and discussion presented by emerging themes}

Between written and oral course evaluations, classroom observations, notes and discussions, we have identified seven important recurring themes expressed by the participants based on frequency and relevance. This type of data collection and participants' feedback served to improve future editions of the course. Some of the participants' contributions will be shown in forms of quotes, in which their English was maintained. The participants in this session are mentioned randomly (and anonymously) and do not follow the order of table 1.

\section{Theory was perceived long and difficult to assimilate}

Eight out of sixteen participants in the written evaluation complained that the theoretical texts to read before each class were too long. This was confirmed by the majority of the participants in the final oral course evaluation, as expressed by one of them: "I did not have enough time to read all the theoretical texts at home, although I realise now that I can keep them for future reference". Their suggestion was to keep the texts shorter or just use the summaries of the power point presentations in class, thus reducing the amount of information received. Those who found the theory less stimulating were also those who found it difficult to understand at first, both for the concepts, the new terminology and the English used. As a consequence, they requested more practical activities. Nonetheless, another participant argued: "I understand that the practical activities were more fun, but for me it was also very important to have a solid theoretical background". For future editions we will try to give practice even more relevance and it is also our intention to include more themes related to trans and intersex identities in the programme, as suggested by two participants in the classroom.

\section{The time issue}

In order to be able to read and analyse all the theoretical texts at home, the participants suggested a longer course with fewer hours per class, as mentioned by one of them:

Yes, I think the problem is the time not the theoretical part, because I know we need it to understand everything, to analyse the books, to watch the movie, to understand what heteronormativity is and whatever, but I think we need more time to go through it all.

However, despite this lack of time, one participant commented: "We had the programme, so I think that you have covered every main issue, this is quite difficult to see, because in these years l've been to university, we almost never covered the whole programme in any course".

\section{Appreciation of practical workshops}

They all admitted having enjoyed all the workshops, especially 'Challenging stereotypes and myths' (GLEE, 2002: 46-47), in which in pairs they had to defend or attack common Igbtiq+phobic statements. This particular workshop was a great opportunity for them to use their English skills 
and put into practice their own life experience together with what they had learnt in the course, as remarked by one participant: "I was not expecting it was going to be like that, people were talking to each other a lot and discussing". Another on the importance of the practical activities:

Practical workshops are important for my future as a primary school teacher, because I might find myself dealing with these situations, and the true is that before, in this university faculty, nobody had ever taught us how to treat problems with children, not only of this type, so, I've found various things in the course that will be useful for my future.

They also enjoyed the films we discussed in class, notably the documentary It's elementary (Chasnoff \& Cohen, 1996), as well as having learnt a great deal through their oral presentations (teaching projects). Moreover, they commented that the practical activities worked well because of the good relationship with the facilitators and the teaching methodology employed in the classroom. They all found the strategies learnt in class to counter Igbtiq+phobia and how to develop a queer pedagogic unit very useful. These activities made them aware of the presence of heteronormativity in EFL education and twelve participants admitted being surprised by this, as commented by one of them: "At the beginning I could not see heteronormativity, now I see it everywhere, every day, it's terrible". They also recognised that Igbtiq+phobia can affect anybody, including cis heterosexuals who are friends (or family members) to queer people and might suffer direct or indirect Igbtiq+phobia for diverse reasons.

\section{English as a language barrier}

Six participants admitted in the oral evaluation that they sometimes struggled when they wanted to participate in class conversations or when they presented their final projects in English. This is a common problem in a mixed-ability foreign or second language class. Nonetheless, it is also comforting that everybody enjoyed the exclusive use of English during the course as they recognised having improved their English language skills and felt relaxed enough to ask us anything they needed. In fact, one participant observed: "I understood all the English used in class, but I found it difficult to express myself in English, although I was very pleased that the course was offered entirely in English as it was the main reason for joining it”. Moreover, another commented:

Also, it is a challenge, because it is difficult to talk about this topic in Spanish, even more in English, we try to understand everything in English, also talking in English, I mean, also explain to them, to children, make it easier for people of 8,10 or 12 years, it's a challenge for us.

And someone else added:

Another challenge: sometimes I was nervous because I was afraid to be misunderstood when I spoke in English and I was all the time, but because you act not like traditional teachers it was not like very serious class, a lot of fun there was mmmh, all these things but not a traditional class, so I was comfortable. 
Although the course participants were all native speakers of Spanish, but with different levels of English, language as a power issue was also critiqued in the Pilot Leadership Training Course of the GLEE Project:

One of the observations during the Pilot Leadership Training Course was that native English speakers spoke in workshops disproportionately more than non-natives. This power issue that led to exclusion raised concerns that it went against the principle of fostering cross-cultural dialogue (Bedford, 2009: 171).

\section{Change of initial perception of gender and sexual identity issues}

The most remarkable change is related to the initial participants' position (eleven out of sixteen) that it was easier to teach sexuality issues in secondary education than in primary education. Towards the end of the course this was reversed as eleven participants believed it was easier to do so with primary school children. According to them, children do not have prejudices, they can think critically, they possess their own knowledge and it is somehow easier to communicate with children than teenagers. This was highlighted by two participants: "I've learnt many things, especially not to underestimate primary school pupils' capacity for understanding sexual identity issues". And: "It's easier with primary school pupils, after seeing It's elementary, because they can understand better prejudices and could be more open-minded and respect better the teacher than secondary school students". Whilst another commented: "I've also changed my mind about some concepts, for example, how to deal with the issue with small children, at the beginning I was against it, and now I think it's important and it's easier". Throughout the course they also learned that they do not need to talk about sex (as in sexual acts) with their pupils and students, but rather focusing on gender and sexual identities as cultural entities and communities within the spectrum of human rights and social (in)justice.

One participant recognised the importance of teaching these issues directly in the classroom: "For me it is still easier at secondary school because students might understand it better, before this course I thought the topic could only be dealt with by 'experts' in sexuality and psychologists, but now I believe teachers can do it".

Another stressed that "because of the atmosphere in the classroom, I really think that those of us who have been regularly to class have dramatically changed our way of thinking".

However, two more students commented that they would be afraid of Igbtiq+phobic reactions if they were to discuss sexuality issues in their classroom. This reaction was mainly provoked by observing the Igbtiq+phobic reality outside the safety environment of our classroom, which they were not aware of before the commencement of the course. Moreover, at first, more than half of the participants were afraid of parental reactions, but towards the end of the course a slight majority (about ten) commented in the classroom that they would in- 
form pupils' and students' parents/guardians if they intended discussing sexuality issues by inviting them to the school to see the documentary It's elementary and to show that Igbtiq+phobia should be addressed as social discrimination and injustice, like others.

\section{Use of class materials for future teaching experiences}

The participants admitted wanting to use the course materials for their teaching career, as stated by one of them: "I will use the material and methodology adopted during the course to teach in future teaching situations". Six participants argued that they would be very careful with the words they choose when they teach gender and sexual identity issues in English, as expressed by one of them:

I really enjoyed this course, because I know I'm going to use a lot of what I learnt here in my practice, classes, also I practiced here with all the things that I learnt, I'm going to be aware with the words that I choose, you know, like when I talk about families, when I talk about love or when I talk about gender.

Four admitted that queer theory and transformative pedagogy helped them learn how to teach respect for all in education, as commented by another participant who stated that she had actually used what she had learnt in the course in a homophobic situation during her training period: "Of course, also something happened in my practice, they talked to a guy (using homophobic slurs), well, and I said 'what happens here?' and I decided to talk to them and to use things I've learnt, so I'm happy for this course".

\section{Importance of being trained and course originality}

All the participants appreciated the training course and underlined the importance of being trained to counter Igbtiq+phobia, gender binarism, heterosexism and cissexism in EFL education for their professional development. Furthermore, the methodology of the course was particularly praised: "The course methodology is totally different from what we've been used to in education, as we are not normally encouraged to discuss or share our opinions in the classroom". Whilst two participants discussed the usefulness of the theme: 'It is a subject that needs discussion at primary school as it is very important, but it is still considered taboo'; and: "I found the subject very interesting because it is something that we never do, ever; also the documentary was interesting and all the videos we saw in class, also the music ones".

As for the necessity to deal with gender and sexual diversity in EFL education one participant said: "Yes, because a foreign language should be studied taking into account all the linguistic and sociolinguistic aspects, as gender and sexual identities are part of cultures and societies; also, English language textbooks are very heterosexist". For most participants, learning how to deal with gender and sexual identity issues is essential because these issues tend to come up in class conversations anyway. Another participant commented: 
For me it was a very useful course because we learned new concepts, like the difference between Hiv and Aids, which I didn't know before, and I learned how to deal with these issues at school, before this course I would have not known how to do it.

This training course offered them latent teacher empowerment on gender and sexual diversity in the area of EFL education which will eventually become active empowerment (Bedford, 2009) when they start teaching as in-service teachers. The course was also praised because it was presented and discussed without taboos.

On the other hand, twelve participants insisted that the major obstacle to teach gender and sexuality issues is represented by the parents/guardians or the school stakeholders (including classmates, colleagues and school staff in general), especially if it is religious. Nonetheless, they all believed that training courses should be offered to in-service and pre-service primary and secondary school English language teachers as part of their learning process. One participant argued: "I did not know Spain, and Andalusia in particular, had progressive legislation for Igbti people, it is never mentioned and I would like to know how to use it to protect my students".

The participants opened themselves up throughout the course due to the issues discussed, which were liberating for them, and this might have contributed to the relaxing and pleasant atmosphere created in class. Moreover, through a personal introspective process, they allowed access that was previously denied. For all these reasons, they recommended this type of course.

\section{Conclusions}

The course participants demonstrated how this type of teacher training is relevant and needed in EFL education in Spain in order to fill a gap which has never been sufficiently covered for all the reasons described in this paper and from the class discussions with the course participants.

It was considered important to have learnt equitable language and strategies to counter the gender binary system, Igbtiq+phobia, heterosexism and cissexism in education, together with the necessity to enact queer sociolinguistics in English language teaching. Almost all the participants considered themselves to be (cis) heterosexual, yet creating a safe environment where everybody was included in the discourses and thus problematising all gender and sexual identities, especially (cis) heterosexuality, in agreement with Nelson (2009). Also, the participants realised that Igbtiq+phobia affects everybody, hence it should be considered and included as a gender and power issue like women's inequity in our society, starting from early childhood education, as commented by the participants and underlined in the study carried out by Warin \& Adriany (2017).

On a more negative side, the course participants realised how relatively easy it was to discuss gender and sexuality issues during the course but how difficult it was to take real action 
outside the course environment, and how hard life could be for some Igbtiq+ persons. This realisation created uneasiness among some participants, who said to try to turn this problem over by contributing to a more equitable education and society for Igbtiq+ persons employing what they learned during the course, thus demonstrating having achieved active teacher empowerment (Bedford, 2009). In fact, five participants contacted us after the course and told us they had successfully put into practice what they had learnt during the course in their EFL classroom. The course also revealed how progressive Spanish legislation in favour of Igbtiq+ people is not generally known by student teachers; the course trainees admitted wanting to learn more about it, especially how to apply it in real class situations.

Looking to the future, this type of training programme, supported by the work of McEntarfer (2016), should be offered to all pre-service and in-service teachers of all educational disciplines and levels, not only EFL teaching, as suggested by the course trainees, as a means to counter the gender binary system, Igbtiq+phobia, heterosexism and cissexism in education.

\section{References}

BarozzI, Stefano, 2016: Training on gender and sexual identities in a Spanish context. Doctoral thesis, University of Granada, Spain [retrieved from: https://bit.ly/2FtıePx].

Barozzi, Stefano, \& Juan R. Guijarro-Ojeda, 2014: "Discussing sexual identities with pre-service primary school English-language teachers in a Spanish context", Perspectives in Education 32, 131-145.

Barozzl, Stefano, \& Juan R. Guijarro-Ojeda, 2016: "Sexual identities in EFL at primary school level: A pre-service teachers' perspective from Spain”, Porta Linguarum 25, 9-20.

BedFord, Timothy, 2002: "Queer developments in teacher education: Addressing sexual diversity, homophobia, and heterosexism" in Rita M. Kissen (ed.): Getting ready for Benjamin. Preparing teachers for sexual diversity in the classroom, Lanham, MD: Rowman \& Littlefield, 133-142.

Bedford, Timothy, 2009: Promoting educational equity through teacher empowerment. Web-assisted transformative action research as a counter-heteronormative praxis, Oulu: Oulu University Press.

BERG, Margaret A., 2012: "Teens' explorations of gender and sexual identities in conversations about/around preferred texts", Journal of Language and Sexuality 1, 15-34.

Bickmore, Kathy, 1999: “Why discuss sexuality in elementary school?” in William J. LetTs IV \& James T. SeARs (eds.): Queering elementary education. Advancing the dialogue about sexualities and schooling, New York, NY: Rowman \& Littlefield, 15-25. 
Blair, Alison, \& Jane Cadwallader, 2009: Galaxy 3, Oxford: OUP.

Bower, Laura A., \& Amanda L. Sature, 2012: "Surpassing Normal: Preparing Teachers for Diverse Learners", Action in Teacher Education 33 (5-6), 416-43.

BRANt, Cathy A. R., 2017: "How do I understand the term queer? Preservice teachers, LGBTQ knowledge, and LGBTQ self-Efficacy", The Educational Forum 81 (1), 35-51.

ButLer, Judith, 1990: Gender trouble. Feminism and the subversion of identity, New York, NY: Routledge.

Chasnoff, Debra, \& Helen S. Cohen, 1996: It's elementary. Talking about gay issues in schools (Film), San Francisco, CA: Women Educational Media.

De Vincenti, Gloria, Angela Giovanangel \& Rowena Ward, 2007: "The queer stopover: How queer travels in the language classroom", Electronic Journal of Foreign Language Teaching 4, 58-72.

EWERT, Marcus, \& Rex RAY, 2008: 10.000 dresses, New York, NY: Seven Stories Press.

Fierstein, Harvey, 2002: The sissy duckling, New York, NY: Simon and Schuster Children's Publishing.

Foucault, Michel, 1976: Histoire de la sexualité 1, Paris: Éditions Gallimard.

FreIRE, Paulo, 1975: Pedagogy of the oppressed, Harmonsworth, GB: Penguin.

Gallardo Linares, Francisco J., \& Víctor M. Escolano López, 2009: Informe sobre la diversidad afectivo-sexual en la formación de docentes, Malaga, Spain: CEDMA.

GiRoux, Henry A., 1997: Pedagogy and the politics of hope: Theory, culture, and schooling. A critical reader, Boulder, CO: Westview Press.

GLEE, 2002: “GLBTQ educational equity project. Leadership training course manual”, unpublished, Oulu University, Finland.

GRAY, John, 2015: The construction of English. Culture, consumerism and promotion in the ELT global coursebook, London, UK: Palgrave Macmillan.

GujJarRo-Ojeda, Juan Ramón, 2004: "Valores de otredad (cultura y género) en libros de texto de inglés para primaria”, Encuentro: Revista de investigación e innovación en la clase de idiomas 15, 32-38.

GuIJARRo-OJedA, Juan Ramón, 2006: “Enseñanzas de la teoría queer para la didáctica de la lengua y la literatura extranjeras”, Porta Linguarum 6, 53-66. 
GuiJARRo-Ojeda, Juan Ramón, \& Raúl Ruiz-CeCILIA, 2011: "Towards a critical analysis of heteronormal discourses in foreign language teacher training”, INTED2011 Proceedings, IATED, 5352-5361.

Guijarro-Ojeda, Juan Ramón, \& Raúl Ruiz-Cecilia, 2013: "Perceptions of Spanish EFL trainee teachers on the introduction of queer issues in the classroom”, Onomázein 27, 193-206.

HanAUER, David, 2007: The closet in the classroom: Re-positioning queer identity as a 'non-issue' in TESOL instruction, Marlen Elliot Harrison, MA: Indiana University of Pennsylvania.

Hermann-Wilmarth, Jill M., \& Patricia BILls, 2010: "Identity shifts: Queering teacher education research", The Teacher Educator 45 (4), 257-272.

Horkheimer, Max, 1976: "Traditional and critical theory" in Paul Connerton (ed.): Critical sociology: Selected readings, London, UK: Penguin: 206-224.

Jagose, Annamarie, 1996: Queer theory: An introduction, New York, NY: NYUP.

Jennings, Kevin, 1999: “Forward” in William J. Letts IV \& James T. Sears (eds.): Queering elementary education. Advancing the dialogue about sexualities and schooling, New York, NY: Rowman \& Littlefield, ix-xi.

KISSEN, Rita M., 2002: Getting ready for Benjamin: Preparing teachers for sexual diversity in the classroom, Lanham, MD: Rowman \& Littlefield.

Kuzmic Jeffrey J., 2014: “Disturbing Masculinities" in Monica TAYLor \& Lesley Cola (eds.): Gender, feminism, and queer theory in the self-study of teacher education practices, Rotterdam, The Netherlands: Sense Publishers, 77-92.

McEntARFER, Heather K., 2016: Navigating gender and sexuality in the classroom, New York, NY: Routledge.

MurRay, Olivia J., 2015: Queer Inclusion in teacher education: Bridging theory, research, and practice, New York, NY: Routledge.

NeLSon, Cynthia D., 1993: “Heterosexism in ESL: Examining our attitudes”, TESOL Quarterly $27,143-150$.

NeLSon, Cynthia D., 1999: "Sexual identities in ESL: Queer theory and classroom inquiry”, TESOL Quarterly 33, 371-391.

Nelson, Cynthia D., 2002: "Why queer theory is useful in teaching: A perspective from English as a second language teaching", Journal of Gay \& Lesbian Social Services 14, 43-53. 
Nelson, Cynthia D., 2009: Sexual identities in English language education: Classroom conversations, New York, NY: Routledge.

PAIz, Joshua M., 2015: "Over the monochrome rainbow. Heteronormativity in ESL reading texts and textbooks", Journal of Language and Sexuality 4 (1), 77-101.

PAPIOL, Elisenda, \& María Tотн, 2009: Bugs world 3, Oxford, UK: Macmillan.

Pérez Fernandez-Figares, Kim, 2012: "Las personas variantes de género en la educación" in Octavio Moreno Cabrera \& Luis Puche Cabezas (eds.): Transexualidad, adolescencias y educación. Miradas multidisciplinares, Madrid, Spain: Egales, 293-303.

Penna Tosso, Melani, 2012: Formación del profesorado en la atención a la diversidad afectivo-sexual. Doctoral thesis, Universidad Complutense de Madrid, Spain [retrieved from: http:// eprints.ucm.es/16718/1/T34011.pdf].

Robinson, Kerry H., \& Criss Jones Díaz, 2006: Diversity and difference in early childhood education, London, UK: Open University Press.

Serano, Julia, 2007: Whipping girl: A transsexual woman on sexism and the scapegoating of femininity, Barkeley, CA: Seal Press.

SeARs, James T., 1999: "Teaching queerly: Some elementary propositions" in William J. LetTs IV \& James T. Sears (eds.): Queering elementary education. Advancing the dialogue about sexualities and schooling, New York, NY: Rowman \& Littlefield, 3-14.

Staley, Sara, \& Bethy Leonardi, 2016: "Learning to discomfort: Preparing literacy teachers for gender and sexual diversity", Research in the Teaching of English 51 (2), 209-229.

Sunderland, Jane, \& Mark McGlashan, 2015: "Heteronormativity in EFL textbooks and in two genres of children's literature (Harry Potter and same-sex parent family picturebooks)", Language Issues 26 (2), 17-26.

TAYLOR, Monica, \& Lesley Cola (eds.), 2014: Gender, feminism, and queer theory in the self-study of teacher education practices, Rotterdam, The Netherlands: Sense Publishers.

Thornbury, Scott, 1999: "Window-dressing vs. cross-dressing in the EFL sub-culture”, Folio 5, 15-17.

Valentine, Johnny, 2004: One dad, two dads, brown dad, blue dads, New York, NY: Alyson Books.

Warin, Joanna, \& Vina Adriany, 2017: "Gender flexible pedagogy in early childhood education”, Journal of Gender Studies 26, 375-386. 
Way, Philippa C., 2016: LGBT Inclusive Materials in ELT. An investigation into teacher and learner responses towards non-heteronormative materials within a UK-based context. M. A. dissertation, University of Surrey, UK [retrieved from: https://bit.ly/2QwltC3]. 